І. М. Звягольська

ORCID https://orcid.org/0000-0001-7531-3966

Т. В. Дерев'янко

ORCID https://orcid.org/0000-0002-5097-8299

Г. А. Лобань

ORCID https://orcid.org/0000-0003-0055-7696 Scopus Author ID 6602341041

Полтавський державний медичний університет, Полтава

\title{
МЕТОДИЧНІ АСПЕКТИ ВИКЛАДАННЯ НАВЧАЛЬНОЇ ДИСЦИПЛІНИ «МІКРОБІОЛОГІЯ 3 ПРОФІЛАКТИКОЮ ІНФЕКЦІЙ» ДЛЯ МАЙБУТНІХ ФАХІВЦІВ-ПАРАМЕДИКІВ
}

\author{
I. M. Zviaholska, T. V. Derevianko, G. A. Loban \\ Poltava State Medical University, Poltava \\ METHODOLOGICAL ASPECTS OF TEACHING THE DISCIPLINE \\ “MICROBIOLOGY WITH INFECTION PREVENTION” FOR FUTURE \\ SPECIALISTS-PARAMEDICS
}

\begin{abstract}
Анотація. Метою нашого дослідження було розкрити завдання та особливості методичного забезпечення навчальної дисципліни «Мікробіологія з профілактикою інфекцій» у процесі професійної підготовки майбутніх фахівців-парамедиків.

У статті розкрито мету, завдання, форми та методи викладання і зміст навчальної дисципліни, знання, вміння та практичні навички, які отримують здобувачі освіти, програмні результати навчання. 3 метою високоякісної підготовки фахівців на кафедрі мікробіології, вірусології та імунології Полтавського державного медичного університету викладачі розробили навчальнометодичний контент дисципліни «Мікробіологія з профілактикою інфекцій».

Встановлено, що вивчення здобувачами освіти навчальної дисципліни «Мікробіологія з профілактикою інфекцій» $\mathrm{\epsilon}$ невід’ємною складовою формування професійно-комунікативної компетентності фахівця кваліфікації «Парамедик», а також особистості висококваліфікованого спеціаліста у сфері екстреної медицини. Під час вивчення дисципліни майбутні фахівціпарамедики оволодівають системою необхідних знань, вмінь та практичних навичок, які $є$ необхідними для подальшої професійної діяльності. Впровадження інтерактивних методів підвищує мотивацію та інтерес здобувачів освіти до навчання, розвиває творче та клінічне мислення, формує усвідомлене відношення до самоосвіти, навчає швидко орієнтуватися і приймати рішення в складних ситуаціях.
\end{abstract}

Ключові слова: мікробіологія з профілактикою інфекцій; здобувач освіти; парамедик; форми та методи навчання.

Abstract. The purpose of our study was to reveal the tasks and features of the methodological support of the discipline "Microbiology with infection prevention” in the process of training future paramedics.

The article reveals the purpose, objectives, forms and methods of teaching and the content of the discipline, knowledge, skills and practical skills of students, program learning outcomes. To provide high-quality training at the Department of Microbiology, Virology and Immunology of Poltava State Medical University, teachers have developed educational and methodological content of the discipline "Microbiology with infection prevention".

It is established that the study of the discipline "Microbiology with Infection Prevention" by students is an integral part of the formation of professional and communicative competence of the specialist "Paramedics", as well as the personality of a highly qualified specialist in emergency medicine. While studying the discipline, future paramedics master the system of necessary knowledge, and practical skills that are necessary for further professional activity. The implementation of interactive methods increases the motivation and interest of students in learning, develops creative and clinical thinking, forms a conscious attitude to self-education, teaches them to quickly navigate and make decisions in difficult situations.

Key words: microbiology with infection prevention; applicant; paramedics; forms and methods of teaching.

(C) I. М. Звягольська, Т. В. Дерев’янко, Г. А. Лобань 
Вступ. У 2017 р. в Україні, під час практичної реалізації реформи екстреної медичної допомоги, з метою покращення іï якості було введено нову кваліфікацію - «Парамедик», яку було внесено до національного класифікатора України, що затверджено наказом Мінекономрозвитку від 26.10.2017 р. № 1542 «Про затвердження Зміни № 6 до національного класифікатора України ДК 003:2010» [5]. Парамедик є фахівцем, який повинен надавати широкий спектр рятувальних медичних послуг на догоспітальному етапі і своєчасно транспортувати потерпілого до медичних установ. Вимоги щодо технічних можливостей і вмінь до парамедиків суттєво вищі порівняно з можливостями фельдшера, адже вони першими надають кваліфіковану допомогу в екстремальних ситуаціях. Сучасний рівень розвитку нашого суспільства вимагає фахівців цієї кваліфікації, які вкрай необхідні в Україні. Окрім того, ця професія є досить престижною в усьому світі. Тому перед медичними закладами освіти постають вагомі виклики щодо організації освітньопізнавального простору на відповідних кафедрах, який підвищить мотивацію навчання фахівців і зумовить ефективність набуття фахових компетентностей $[1,4]$.

3 цією метою Навчально-науковий медичний інститут Полтавського державного медичного університету (ПДМУ) здійснює високоякісну підготовку фахівців відповідно до освітньо-професійної програми «Парамедик» першого (бакалаврського) рівня вищої освіти за спеціальністю 223 «Медсестринство» галузі знань 22 «Охорона здоров’я». Навчальна дисципліна «Мікробіологія з профілактикою інфекцій» є однією з невід’ємних складових формування професійно-комунікативної компетентності майбутнього фахівця кваліфікації «Парамедик».

Мета статті - розкрити завдання та особливості методичного забезпечення навчальної дисципліни «Мікробіологія з профілактикою інфекцій» у процесі професійної підготовки майбутніх фахівцівпарамедиків.

Теоретична частина. Відповідно до вимог освітньо-професійної програми «Парамедик» першого (бакалаврського) рівня вищої освіти за спеціальністю 223 «Медсестринство» галузі знань 22 «Охорона здоров’я» навчальна дисципліна «Мікробіологія з профілактикою інфекцій» вивчається на другому році навчання в ПДМУ та забезпечує набуття здобувачами освіти інтегральних, загальних і фахових компетентностей [5], таких, як:
1. Інтегральна - здатність розв'язувати складні задачі і проблеми у галузі надання екстреної медичної допомоги на доушпиталеному та ранньому ушпиталеному етапах або у процесі навчання, що передбачає застосування певних теорій та методів відповідної науки, проведення досліджень та/або здійснення інновацій і характеризується комплексністю та невизначеністю умов і вимог.

2. Загальні - здатність навчатися та самонавчатися; здатність застосовувати знання на практиці; здатність працювати в команді та брати на себе відповідальність; здатність використовувати інформаційні та комунікаційні технології; відповідально ставитися до завдань і обов'язків.

3. Фахові - здатність оцінити місце події на наявність загроз власному життю і життю інших людей, виявити фактори, що впливають на стан та здоров’я пацієнтів, і забезпечити власну безпеку; здатність прийняти рішення про обсяг допомоги та госпіталізацію.

3 метою високоякісної підготовки фахівців на кафедрі мікробіології, вірусології та імунології ПДМУ викладачі розробили навчально-методичний контент дисципліни «Мікробіологія з профілактикою інфекцій», який включає такі компоненти: навчальну програму дисципліни, робочу програму дисципліни, силабус навчальної дисципліни, методичні вказівки для самостійної роботи студентів під час підготовки до практичного заняття та на занятті, методичні розробки лекцій, питання та завдання до підсумкового модульного контролю тощо.

Вивчення дисципліни «Мікробіологія з профілактикою інфекцій» нерозривно пов'язане з використанням знань, одержаних здобувачами освіти в середній загальноосвітній школі з навчального предмета «Біологія», а також знань і вмінь, отриманих студентами на першому курсі навчання при вивченні дисциплін із циклів загальної та професійної («Латинська мова та медична термінологія», «Анатомія», «Фізіологія») підготовки.

Мікробіологія з профілактикою інфекцій закладає фундамент необхідних знань, умінь та навичок для подальшого вивчення студентами профільних навчальних дисциплін («Основи епідеміології», «Громадська безпека та безпека життєдіяльності», «Організація екстреної медичної допомоги», «Невідкладні стани в педіатрії», «Обстеження та визначення стану пацієнта», «Екстрена допомога при травмах» та інших), сприяє розвитку інноваційного клінічного стилю мислення фахівця-пара- 
медика, що грунтується на доказових міжнародних стандартах і протоколах надання екстреної медичної допомоги.

Метою вивчення навчальної дисципліни є сформувати у здобувачів освіти систему знань про загальні закономірності будови, життєдіяльності і розповсюдження патогенних та умовно-патогенних мікроорганізмів, їх основні групи факторів патогенності й етіологічну роль мікроорганізмів у виникненні і розвитку інфекційних захворювань, основи сучасних мікробіологічних методів діагностики інфекційних захворювань та методів ідентифікації мікроорганізмів, а також загальні принципи специфічної та неспецифічної профілактики і лікування захворювань, спричинених інфекційними агентами.

Вивчення курсу «Мікробіологія з профілактикою інфекцій» передбачає формування у здобувачів медичної освіти теоретичних знань і професійних компетенцій, що забезпечують:

- оволодіння знаннями про біологічні властивості мікроорганізмів та закономірності їх взаємодії з макроорганізмом;

- навчання визначати джерела, механізми та шляхи передачі збудників інфекційних захворювань;

- навчання розкривати основні механізми формування імунної відповіді організму людини;

- опанування студентами визначати методи мікробіологічної діагностики інфекційних хвороб;

- ознайомлення із сучасними фундаментальнонауковими й прикладними аспектами основних профілактичних заходів у боротьбі з інфекційними захворюваннями;

- навчання ефективно формувати комунікаційну стратегію у професійній діяльності.

Програма курсу складається з одного модуля «Загальна та спеціальна мікробіологія», який включає в себе 7 змістових модулів (1. Вступ до мікробіології. Мікробіологія, фізіологія та генетика мікроорганізмів. 2. Мікробіологічні основи антимікробної терапії. 3. Вчення про інфекцію. 4. Вчення про імунітет. Імунопрофілактика та імунотерапія. Алергія. 5. Спеціальна бактеріологія. 6. Загальна та спеціальна вірусологія. 7. Клінічна та санітарна мікробіологія) і передбачає засвоєння таких практичних навичок:

- виготовляти та мікроскопіювати мазки-препарати для мікроскопічного дослідження;

- фарбувати мазки-препарати простим і складними методами;

- визначити морфологічні та тинкторіальні властивості збудників під мікроскопом;
- аналізувати ріст мікроорганізмів на поживних середовищах;

- проводити дезінфекцію рук, робочого місця, медичного інвентарю, патологічного матеріалу;

- визначити чутливість мікроорганізмів до хіміотерапевтичних препаратів і антибіотиків (метод серійних розведень і диско-дифузійний метод);

- провести облік оцінки результатів серологічних реакцій аглютинації, преципітації, зв’ язування комплементу;

- здійснювати облік результатів реакції, які виконуються у вірусології (гальмування гемаглютинації, нейтралізації вірусів);

- визначати методи мікробіологічної діагностики, етіотропної терапії та профілактики інфекцій, викликаних патогенними прокаріотами та еукаріотами.

Процес активізації навчання вимагає спільної діяльності стейкхолдерів освітнього процесу, застосування різноманітних засобів, форм, системи дій, прийомів, спрямованих на розв'язання освітніх завдань. У процесі навчання дисципліни використовується широкий спектр традиційних та інноваційних методів навчання:

- вербальні (лекція, пояснення, розповідь, бесіда, інструктаж);

- наочні (спостереження, ілюстрація, демонстрація);

- практичні (проведення експерименту, практичних завдань);

- пояснювально-ілюстративні або інформаційно-рецептивні;

- репродуктивні, в основу яких покладено виконання різного роду завдань за зразком;

- метод проблемного викладу, котрий полягає в тому, що викладач ставить проблему і сам її вирішує, демонструючи протиріччя, якими характеризується процес пізнання;

- частково-пошукові або евристичні методи, спрямовані на оволодіння окремими елементами пошукової діяльності, наприклад: викладач формулює проблему, студенти - гіпотезу;

- дослідницькі методи, сутність яких полягає в організації викладачем пошукової творчої діяльності студентів шляхом постановки нових проблем і проблемних завдань.

Вищезазначені методи навчання за своєю спрямованістю органічно поєднуються з наступними групами методів, які методично впроваджуються на кафедрі мікробіології, вірусології та імунології під час навчання парамедиків: 
- методи, що забезпечують сприймання і засвоєння знань студентами (лекції, самостійна робота, інструктаж, консультація);

- методи застосування знань і набуття, закріплення умінь і навичок (практичні заняття, контрольні завдання);

- методи перевірки й оцінювання знань, умінь і навичок;

- методи заохочення і «покарання».

Традиційно, лекційний курс знайомить здобувачів освіти з найбільш актуальними проблемами мікробіології, загалом орієнтує студентів у спеціальних тематично-теоретичних питаннях, визначає вертикальний і горизонтальний міждисциплінарний зв’язок між розділами дисципліни, подаючи їм практичну спрямованість. Згідно з програмою дисципліни здобувачам освіти запропоновано такі теми лекційних занять:

1. Мікробіологія як наука. Морфологія і фізіологія мікроорганізмів.

2. Вчення про інфекцію.

3. Вчення про імунітет.

4. Патогенні коки та ентеробактерії.

5. Збудники повітряно-краплинних бактеріальних інфекцій (дифтерії, туберкульозу, кашлюку).

6. Загальна характеристика РНК-геномних вірусів (ортоміксо-, параміксо-, пікорна-, арбовіруси).

7. РНК-геномні віруси (ретро- та рабдовіруси).

8. Загальна характеристика ДНК-геномних вірусів (гепадно- та герпесвіруси).

Виклад кожної лекційної теми проводиться на відповідному навчально-методичному рівні, щоб забезпечити студенту розуміння складових фрагментів тем дисципліни «Мікробіологія з профілактикою інфекцій» і подальше успішне знаходження необхідних довідкових матеріалів. Під час проведення лекцій доцільним є застосування інтерактивних форм навчання [3]. До кожної лекції розроблено мультимедійні презентації, підібрано пакет відеосюжетів, які сприяють підвищенню інтересу та мотивації навчання. Таким чином, методичне наповнення кожної лекції мотивує здобувачів освіти до активного їх навчання в освітньо-пізнавальному просторі кафедри мікробіології, вірусології та імунології.

Підтримується постійний зворотний зв’язок від студентів під час читання лекцій і проведення практичних занять. Тому важливе місце у викладанні мікробіології займають заняття із застосуванням диспутів і дискусій. Така форма роботи дозволяє краще засвоювати теоретичний матеріал, розвиває логічне мислення студента [1, 4]. Для спонукан- ня до активної навчально-пізнавальної діяльності вже з першого практичного заняття та лекції викладач оприлюднює кінцеві результати навчання на кафедрі мікробіології, вірусології та імунології, аргументуючи значимість кожної складової на реальних конкретних прикладах із практичної діяльності парамедика.

Після завершення вивчення навчальної дисципліни «Мікробіологія з профілактикою інфекцій» здобувачі освіти повинні знати:

- біологічні властивості патогенних та непатогенних мікроорганізмів і закономірності їх взаємодії $з$ макроорганізмом, з популяцією людини та зовнішнім середовищем;

- методи мікробіологічної і вірусологічної діагностики, етіотропної терапії та специфічної профілактики інфекційних хвороб;

- будову імунної системи організму людини;

- основні механізми формування імунної відповіді організму людини;

- основні типи патологічної реакції імунної системи і зв'язок із виникненням найбільш поширених хвороб людини;

- принципи специфічної профілактики та лікування інфекційних захворювань і патології, викликаних умовно-патогенними мікроорганізмами;

- принципи бактеріоскопічної, бактеріологічної, серологічної, біологічної та молекулярно-генетичної діагностики інфекційних захворювань;

- способи отримання, стандартизації та принципи застосування біологічних препаратів: вакцин, сироваток, анатоксинів, імуноглобулінів.

Студенти повинні вміти:

- інтерпретувати біологічні властивості патогенних та непатогенних мікроорганізмів і закономірності їх взаємодії з макроорганізмом, з популяцією людини та зовнішнім середовищем;

- визначати методи мікробіологічної і вірусологічної діагностики, етіотропної терапії та специфічної профілактики інфекційних хвороб;

- пояснювати будову імунної системи організму людини;

- трактувати основні механізми формування імунної відповіді організму людини;

- визначати основні типи патологічної реакції імунної системи і зв'язок із виникненням найбільш поширених хвороб людини;

- застосувати знання зі специфічної профілактики та лікування інфекційних захворювань і патології, викликаних умовно-патогенними мікроорганізмами, на практиці; 
- використовувати бактеріоскопічні, бактеріологічні, серологічні, біологічні та молекулярно-генетичні методи для діагностики інфекційних захворювань й інтерпретувати їх результати;

- оцінити особливості симптоматики, етіології та патогенезу імунопатологічних станів і вибрати способи їх корекції;

- застосовувати на практиці способи отримання, стандартизації та принципи застосування біологічних препаратів: вакцин, сироваток, анатоксинів, імуноглобулінів.

Особливий акцент під час вивчення дисципліни зроблено на методично грамотне проведення практичних занять, що сприяє поглибленню, розширенню і закріпленню знань студентів, формуванню практичних вмінь і навичок, розвитку клінічного та наукового мислення, і дозволяє перевірити й оцінити якість набутих знань та вмінь майбутніх парамедиків. Зміст практичного заняття визначається навчальним планом і робочою програмою дисципліни «Мікробіологія з профілактикою інфекцій», проте ефективність реалізації значною мірою залежить від досвіду і педагогічної майстерності викладача. Залежно від тематики практичних занять викладачі кафедри використовують різні форми навчальної роботи, такі, як: фронтальна, групова (ланкова, бригадна, кооперативно-групова, диференційно-групова) та індивідуальна. Зокрема, обирають інтерактивні форми й методи проведення занять, які спрямовані на виховання у студентів здатності і потреби логічно висловлювати свої думки в усній чи письмовій формах, брати участь у дискусіях, оволодівати мистецтвом ставити запитання тощо [3]. Після ретельної попередньої підготовки викладачі на певних практичних заняттях можуть використовувати метод мозкового штурму, кейс-метод, метод евристичних питань, вільних асоціацій та ін. На кожному практичному занятті здійснюється поточний контроль знань відповідно до поставлених цілей теми, що дає змогу виявити рівень засвоєння окремих елементів навчального матеріалу. Оцінюється теоретична, практична підготовка та самостійна робота студента як підготовка до аудиторних занять.

Зміст самостійної роботи студента над дисципліною «Мікробіологія з профілактикою інфекцій» визначається робочою навчальною програмою, методичними матеріалами, завданнями та реко- мендаціями викладача. Самостійна аудиторна робота передбачає виконання певних практичних завдань, підготовку усних доповідей із мультимедійним супроводом, розв’язок ситуаційних професійно-спрямованих тестових завдань, аналітичних повідомлень за новітніми досягненнями в галузі медичної мікробіології. Формування творчого потенціалу майбутніх парамедиків відбувається і в процесі активної їх участі в позааудиторній роботі кафедри, що сприяє самостійності студентів, їх ініціативності та творчості [2]. Навчальний матеріал, передбачений для опанування здобувачем освіти у процесі його самостійної роботи, виноситься на поточний і підсумковий контроль. Контроль за самостійною роботою здійснюється викладачем у формі співбесіди на практичних заняттях, перевірки записів у робочих зошитах, тестової перевірки знань. Методика організації самостійної роботи поетапно структурована від первинних знань й уявлень про мікроорганізми до дієвого та усвідомленого оволодіння теоретичними базовими знаннями і практичними навичками з галузі медичної мікробіології, а також вміння органічно їх використовувати в конкретній ситуації майбутньої практичної діяльності парамедика.

Висновки та перспективи подальших досліджень. Таким чином, вивчення здобувачами освіти навчальної дисципліни «Мікробіологія з профілактикою інфекцій» є невід’ ємною складовою формування професійно-комунікативної компетентності фахівця кваліфікації «Парамедик», а також особистості висококваліфікованого спеціаліста у сфері екстреної медицини. Під час вивчення дисципліни майбутні фахівці-парамедики оволодівають системою необхідних знань, вмінь та практичних навичок, які є необхідними для подальшої професійної діяльності. Впровадження інтерактивних методів підвищує мотивацію та інтерес здобувачів освіти до навчання, розвиває творче та клінічне мислення, формує усвідомлене відношення до самоосвіти, навчає швидко орієнтуватися і приймати рішення в складних ситуаціях.

Перспективою подальших досліджень є проведення оцінки якості засвоєння знань та вмінь здобувачами освіти кваліфікації «Парамедик» 3 навчальної дисципліни «Мікробіологія з профілактикою інфекцій». 


\section{Список літератури}

1. Дерев'янко Т. В. Мотивація як чинник успішного формування навчальної діяльності здобувачів медичної освіти в умовах модернізованого освітнього середовища кафедри мікробіології, вірусології та імунології / Т. В. Дерев’янко, І. М. Звягольська // Методика навчання природничих дисциплін у середній та вищій школі (XXVIII Каришинські читання) : матеріали Міжнар. наук.-практ. конф. - Полтава, 2021. - С. 130-131.

2. Дерев'янко Т. В. Формування особистості майбутнього лікаря в контексті позааудиторної роботи на кафедрі мікробіології, вірусології та імунології: досвід і перспективи / Т. В. Дерев’янко, І. М. Звягольська // Медична освіта. - 2020. - № 1. - С. 5-10.

3. Звягольська I. М. Форми і методи навчання іноземних студентів в умовах модернізованого освітнього середовища кафедри мікробіології, вірусології та імунології / І. М. Звягольська, В. П. Полянська, Т. В. Дерев’янко // Актуальні питання медичної

\section{References}

1. Derevianko, T.V., \& Zviaholska, I.M. (2021). Motyvatsiya yak chynnyk uspishnoho formuvannya navchal'noyi diyalnosti zdobuvachiv medychnoyi osvity v umovakh modernizovanoho osvitnioho seredovyshcha kafedry mikrobiolohiyi, virusolohiyi ta imunolohiyi [Motivation as a factor of successful formation of educational activity of medical education seekers in the conditions of modernized educational environment of the department of microbiology, virology and immunology]. Metodyka navchannya pryrodnychykh dystsyplin u seredniy ta vyshchiy shkoli (XXVIII Karyshynski chytannya): materialy Mizhnarodnoyi naukovo-praktychnshchyi konferentsiyi Methods of teaching natural sciences in secondary and higher school (XXVIII Karyshyn readings): materials of the International scientific-practical conference. Poltava [in Ukrainian].

2. Derevianko, T.V., \& Zviaholska, I.M. (2020). Formuvannya osobystosti maybutnoho likarya v konteksti pozaaudytornoyi roboty na kafedri mikrobiolohiyi, virusolohiyi ta imunolohiyi: dosvid i perspektyvy [Formation of the personality of a future doctor through extracurricular activities at the department of microbiology, virology and immunology: experience and perspectives]. Medychna osvita - Medical Education, 1, 5-10 [in Ukrainian].

3. Zviaholska, I.M., Polianska, V.P., \& Derevianko, T.V. (2018). Formy i metody navchannya inozemnykh studentiv v umovakh modernizovanoho osvitnoho seredovyshcha kafedry mikrobiolohiyi, virusolohiyi ta imunolohiyi [Forms and methods of teaching foreign students in a modernized educational environment of the Department of Microbiology, Virology and Immunology]. Aktualni pytannya medychnoyi (фармацевтичної) освіти іноземних громадян: проблеми та перспективи : зб. статей навч.-наук. конф. $з$ міжнар. участю. - Полтава, 2018. - С. 33-36.

4. Звягольська I. М. Шляхи підвищення навчальнопізнавальної діяльності студентів при вивченні дисципліни «Мікробіологія, вірусологія та імунологія» у вищому медичному закладі / І. М. Звягольська, В. П. Полянська, Т. В. Дерев’янко // Актуальні питання лінгвістики, професійної лінгводидактики, психології і педагогіки вищої школи : матеріали IV Міжнар. наук.-практ. конф. - Полтава, 2019. - С. 125-130.

5. Освітньо-професійна програма та технологія підготовки парамедиків у Тернопільському національному медичному університеті імені І. Я. Горбачевського МОЗ України / М. М. Корда, А. А. Гудима, А. Г. Шульгай, С. Й. Запорожан // Медична освіта. - 2019. - № 3 (додаток). - С. 6-14.

(farmatsevtychnoyi) osvity inozemnykh hromadyan: problemy ta perspektyvy: zbirnyk statey navchalnonaukovoyi konferentsiyi z mizhnarodnoyu uchastyu - Current issues of medical (pharmaceutical) education of foreign citizens: problems and prospects: a collection of articles of the educational-scientific conference with international participation. Poltava [in Ukrainian].

4. Zviaholska, I.M., Polianska, V.P., \& Derevianko, T.V. (2019). Shlyakhy pidvyshchennya navchalno-piznavalnoyi diyalnosti studentiv pry vyvchenni dystsypliny «Mikrobiolohiya, virusolohiya ta imunolohiya» u vyshchomu medychnomu zakladi [Ways to increase the educational and cognitive activities of students in the study of the discipline "Microbiology, Virology and Immunology" in higher medical institution]. Aktualni pytannya linhvistyky, profesiynoyi linhvodydaktyky, psykholohiyi i pedahohiky vyshchoyi shkoly: materialy IV Mizhnarodnoyi naukovopraktychnoyi konferentsiyi - Current issues of linguistics, professional language didactics, psychology and pedagogy of higher education: materials of the International Scientific and Practical Conference. Poltava [in Ukrainian].

5. Korda, M.M., Hudyma, A.A., Shulhay, A.H., \& Zaporozhan, S.Y. (2019). Osvitnio-profesiyna prohrama ta tekhnolohiya pidhotovky paramedykiv u Ternopilskomu natsionalnomu medychnomu universyteti imeni I.Ya. Horbachevskoho MOZ Ukrayiny [Educationalprofessional program and technology of training of paramedics in I. Horbachevsky Ternopil National Medical University]. Medychna osvita-Medical Education, 3 , 6-14 [in Ukrainian]. 